\title{
HAKIKAT PENDIDIKAN PESANTREN: Studi atas Falsafah, Idealisme dan Manajemen Pendidikan Pondok Pesantren Al-Islam Kemuja Mendobarat Bangka
}

\author{
Rusydi Sulaiman \\ Fakultas Dakwah \\ IAIN Syaikh Abdurrahman Siddik Bangka Belitung, Indonesia \\ abirusydi@yahoo.co.id
}

\begin{abstract}
Pondok Pesantren has a spesific tradition that is far different with other institutions. It has sub-culture relating with way of life, system of values, system of power and authority in its administration. As the oldest education (indegenous) in Indonesia, ofcourse it had given high cultural and scientific contribution for community. Then the modernization changed the sub-culture and pillars of pesantren. In fact, many changed and a few of this institution withstood and reserved. This article analyzes Pondok Pesantren Al-Islam Kemuja as an educational institution in Bangka Belitung related to its basic aspects called "Philosophy and Idealism", consist of basic values, pesantren's traditional and its spirit (ruh al-Ma'had), also its institutional management. There are some aspects should be strenghened in pesantren: academic, administrative, net-working and so on AlIslam has a special colour. Beside conserving its traditional values, this pesantren should be accomodative toward next valuable thing (al-Muhaafazah 'alaa al-Qadiim al-Shaalih wa al-Akhdzu bi al-Jadiidi al-Ashlah). It is regarding that pesantren as fortresses for the defence of Islamic community and center for dissemination of Islam including Pondok Pesantren Al-Islam Kemuja which situated at small village, Kemuja Mendobarat Bangka Kepulauan Bangka Belitung.
\end{abstract}

Keywords: Education, Pondok Pesantren, philosophy, idealism, institutional management

\section{A. Pendahuluan}

Pesantren merupakan lembaga pendidikan tertua yang memiliki basis tradisional yang mampu bertahan lama di bumi Nusantara hingga kini. Kekuatan akarnya di negeri ini; sosio-kultur dan ruh keislaman menjadikannya berkarakter lokal dan indegenous. Sudah pasti tidak mudah membangun suprastruktur sekuat dan sesolid pondok pesantren. Lembaga tersebut bukan hanya tampil secara konsisten dalam menyelenggarakan forum- 
forum pembelajaran khas pesantren, ${ }^{1}$ melainkan ia telah melewati babak sejarah yang cukup panjang untuk mempertahankan suvavilitas kelembagaannya.

Pesantren telah membuktikan dirinya sebagai suatu lembaga pendidikan Islam yang established (mapan) dan memiliki posisi strategis dalam dunia pendidikan di Indonesia. Perubahan-perubahan sosial, politik, budaya dan lain-lain sejauh ini nampaknya tidak begitu berpengaruh terhadap eksistensi pesantren. Ia memberikan sentuhan tersendiri bagi masyarakat. Hal tersebut telah dibuktikan oleh pesantren berupa kontribusi besar bagi semangat mencerdaskan generasi bangsa dan penguatan peradaban. Tiga fungsi ganda pesantren adalah: pertama, sebagai lembaga pendidikan keagamaan yang berfungsi untuk menyebarluaskan dan mengembangkan ilmu-ilmu keagamaan Islam. Kedua, sebagai lembaga pengkaderan yang berhasil mencetak kader umat dan kader bangsa. Umumnya kader-kader tersebut memperoleh pengakuan sosial (social recognition) yang luas. Ketiga, berfungsi sebagai agen reformasi sosial yang menciptakan perubahan dan perbaikan dalam kehidupan masyarakat. Hal terakhir ini mungkin saja terjadi karena pesantren dengan figur sentral kyai mempunyai pengaruh yang kuat di kalangan masyarakat sekitar sehingga dapat melakukan mobilisasi yang cepat dan efektif. ${ }^{2}$

Layaknya lembaga pada umumnya, setelah mengalami sejarah panjang kiprahnya, pondok pesantren mengalami perubahan. Utamanya akhir-akhir ini lembaga tersebut begitu disoroti keberadaannya. Kenyataannya benar bahwa pesantren sedikit mengalami pergeseran. Terkadang idealisme pendahulunya tergadaikan oleh pengaruh luar yang sangat kencang. Alih-alih memberdayakan masyarakat, mengelola dirinya sendirinya pun tidak kuat. Bahkan ditemukan beberapa pesantren yang terhenti (kolaps) disebabkan oleh

\footnotetext{
${ }^{1}$ Forum-forum tersebut menunjukkan cara pengajaran yang unik. Sang Iyai yang biasanya pendiri sekaligus pemilik pesantren, membacakan manuskrip-manuskrip keagamaan klasik berbahasa Arab (dikenal dengan sebutan "kitab kuning"). Sementara para santri mendengarkan sambil memberi catatan (ngesahi, jawa) pada halaman-halaman kitab yang sedang dibaca. Metode ini disebut bandongan atau semacam collective learning process. Selain itu para santri juga ditugaskan membaca kitab, sementara kiyai atau ustadz menyimak sambil mengoreksi dan mengevaluasi bacaan dan performance seorang santri satu persatu. Metode ini dikenal dengan istilah sorogan atau semacam individual learning proses. Kegiatan belajar-mengajar di atas berlangsung tanpa penjenjangan kelas dan kurikulum yang ketat, dan biasanya dengan memisahkan jenis kelamin siswa/ santri. Lihat Amin Haedari, Transformasi Pesantren; Pengembangan Aspek Pendidikan Keagamaan dan Sosial, (Jakarta: LekDis dan Media Nusantara, 2006), h. 26

2 M.Din Syamsuddin, Etika Agama dalam Membangun Masyarakat Madani, (Jakarta: Logos Wacana Ilmu dan Pemikiran, 2000), h.101-102. Lihat juga K.H. Hasan Abdul Wafi, Wawasan Pendidikan Pondok Pesantren Nurul Jadid, Makalah disampaikan pada acara seminar dan lokakarya di Ponpes Nurul Jadid, Paiton Probolinggo, 8-9 Agustus 1991.
} 
tidak adanya generasi kuat yang mampu mengendalikannya. Konfliks di internal pesantren bisa jadi sebagai faktor lemahnya kelembagaan pondok pesantren. Belum lagi pengaruh luar. Situasi tersebut setidaknya berpengaruh terhadap kontinuitas sebuah lembaga pendidikan semacam pesantren. Hal tersebut juga menyentuh keberadaan beberapa pondok pesantren di kep. Bangka Belitung yang secara kelembagaan umumnya mengalami perbedaan sehingga perlu ditelusuri sejauh mana lembaga-lembaga tersebut mengambil sikap.

Pesantren al-Islam kemuja Mendobarat Bangka — selanjutnya disebut Pon Pes alIslam juga menjadi sorotan penulis. Lembaga pendidikan yang terletak di Desa Kemuja tersebut tergolong tua dan yang mengawali intensifikasi Islam dengan corak tertentu. Awalnya bercorak, "salaf" (mengajarkan kitab-kitab kuning) kemudian bergeser menjadi, "khalaf" (menganut kurikulum modern). Tidak terlalu jelas sikap yang ditonjolkan—antara salaf dan khalaf. Sejatinya ia mengalami kemajuan pesat melebihi beberapa lembaga pendidikan yang relatif muda, karena digagas atas dasar falsafah dan idealisme pendahulu yang kuat. Merosotnya beberapa aspek yang semestinya melekat- menyisakan pertanyaan bagi penulis dan kemudian memotivasi diri untuk lakukan trobosan pearadaban, yaitu mempertahankan eksistensi pondok pesantren sebagai lembaga pendidikan Islam. Jangan sampai kelembagaan pondok pesantren tersebut tergadaikan begitu saja hanya oleh kecenderungan pragmatis sebagian orang di dalamnya, dan lembaga mesti dikembalikan eksistensi kelembagaannya agar tetap menjadi panutan masyarakat.

Terlebih mencermati perkembangan sains dan teknologi modern yang seringkali diidentikkan dengan Barat karena keunggulan aspek-aspek tertentu, maka Pondok Pesantren-terlebih Pon Pes al-Islam perlu mengambil langkah antsipatif dan juga membekali dirinya dengan aspek-aspek tertentu. Apalagi pesantren tidak setangguh dulu dan jumlah santrinya pun beragam serta kualitas alumni sebagai lulusan lembaga tersebut mengalami penurunan. Jiwa dan nilai-nilai positif kepesantrenan yang sangat khas dipersepsikan lambat laun terkikis bersamaan dengan lemahnya prinsip-prinsip yang dipegang oleh komunitas pesantren, harus digali kembali, dan manajemen pengelolaannya juga diperkuat kembali.

Satu aspek yang sangat perlu dilakukan penguatannya adalah kelembagaan pesantren. Pesantren tidak muncul tiba-tiba dalam periode sejarah tertentu, melainkan melalui pengorbanan dan perjuangan panjang para pendahulunya. Falsafah dan idealisme 
yang digagas sebagai bagian dari prinsip pendidikan harus mendasari pendirian pondok pesantren sebelum mengawali pembaharuan pendidikan. Kondisi beberapa pondok pesantren di kepulauan ini juga memotivasi penulis untuk secara mendalam meneliti tentang kelembagaan institusi tersebut, setidaknya ia diperhitungkan karena melahirkan generasi-generasi muda berkualitas.

\section{B. Hakikat Pesantren}

Pondok pesantren adalah lembaga pendidikan yang kental dengan kekhasan masyarakat disekitarnya; tradisional Islam. Lembaga tersebut selain mengamalkan ajaran Islam, juga menekankan moral keagamaan sebagai pedoman perilaku. Dalam pengertian sempit, pesantren bukan hanya merupakan lembaga pendidikan Islam dan pusat penyebaran Islam, tetapi ia merupakan benteng pertahanan umat (defence of Islamic community) dan institusi yang melestarikan budaya religius. Tidak mudah merintis sebuah pesantren apalagi mempertahankan keutuhannya di tengah hiruk pikuk politik dan tekanan pengaruh eksternal lainnya.

Secara spesifik, ia merupakan sebuah lembaga pendidikan yang otoritas tertingginya berada di tangan seorang kyai dan masjid sebagai pusat kegiatan keagamaan. Awalnya terbentuk dari kesiapan psikologis seorang kyai dengan segala dedikasinya, bermukim di suatu wilayah yang sebelumnya tidak pernah dijamah orang, kemudian hadir beberapa orang calon santri yang ingin belajar kepadanya dan bermukim di tempat tersebut. Dengan bertambahnya jumlah santri, mereka pun mendirikan pondok kecil atau asrama tempat tinggal di sekitar kediaman kyai atau masjid. Umumnya lahan tanah sebagai cikal bakal lokasi pondok adalah milik kyai yang diwakafkan untuk kepentingan umat. ${ }^{3}$ Hal tersebut berbeda dengan umumnya proses pembentukan pesantren belakangan ini. Seorang kyai-pengasuh pesantren didatangkan setelah asrama dan gedung sekolah di lingkungan pesantren dibangun. Disayangkan, terkadang kyai tersebut tidak mengenal kultur dan adat istiadat setempat sehingga tertolak keberadaannya di tengaj masyarakat.

${ }^{3}$ Zulkifli, Sufism in Java: The Role of the Pesantren in the Maintenance of Sufism in Java, (Jakarta: INIS, 2002), h.1 
Istilah umum dalam bahasa Arab untuk menamakan sebuah pesantren adalah "al-Ma'had", dan dalam Bahasa Inggris dikenal "Boarding School" atau "Islamic Boarding School". Kata "pesantren" terdiri dari kata "santri" dengan awalan "pe" dan akhiran "an', mengandung pengertian tempat tinggal para santri. Menurut sebagian ahli sebagaimana dikutip Zamakhsyari Dhofier, bahwa istilah "santri" berasal dari kata"shastri" (Bahasa India) berarti orang yang banyak tahu buku-buku suci agama Hindu. Kata "Shastri" terderivasi dari istilah "Shastra", yaitu buku-buku suci agama atau buku-buku tentang ilmu pengetahuan. ${ }^{6}$

Dalam kaitannya dengan pesantren, santri merupakan sosok yang mendalami ilmu agama Islam. Dan kata pesantren, paling tidak terdiri dari elemen santri ini ${ }^{7}$ disamping elemen-elemen lain sebagai berikut, yaitu: kyai, masjid, asrama atau pondok dan materimateri pelajaran. Dan kyai adalah elemen dasar yang sangat pokok, karena ia sosok yang menggagas pembentukan sebuah pesantren dan membina para santri. ${ }^{8}$ Kyai identik dengan ulama walaupun tidak selalu memimpin sebuah pesantren, karena pengaruhnya di

${ }^{4}$ Kata "al-Ma'had" berasal dari kata " "ahida- ya'hadu- 'ahdan" (al-Amr) "'arafahu" (mengenal), "hafizhahu", memelihara), "wa ra'aahu” (membimbing). Kata "ma'had' adalah mufrad, dan bentuk jamaknya adalah "ma'ahid" ( al-makan fiihi al-Syai'u) atau al-makan alladzi la yazaalu al-Qaumu yarji'uuna ilaihi). Lihat Abu Luis Ma'luf, al-Munjid fi al-Lughah, (Beirut: Dar al-Masyriq, 1977).cet 22.,h. 535. Lihat juga Atabik Ali, kamus Kontemporer Arab Indonesia, (jogyakarta: Multi Karya Grafika Pon Pes Krapyak).,h. 1770

5 "Religious Boarding School, Islamic training College dan Islamic College", Juga kadang disebut "Islamic Institute". Lihat juga dalam Abdurrahman Mas'ud dalam The Pesantren Architects and their socio-religious Teaching (1850-1950), (Disertasi belum dipiblikasikan), university of california Los Angeles, 1997.,h.1-3

${ }^{6}$ Zamakhsari Dhofier, Tradisi Pesantren, Studi tentang Pandangan Hidup Kiyai, (Jakarta: LP3ES, 1982).,h. 18. Dalam bahasa Melayu disebut "santeri". Shastri adalah bahasa Sansakerta, "Sattiri" adalah Bahasa Tamil, adalah pelajar (learner) atau ulama (schoolar). lihat dalam Mark R.Woodward, Islam Jawa; Kesalehan Normatif versus Kebatinan, terjemahan Kairus Salim SA dari Islam in Java; Normative Piety and Mysticism, (Jogyakarta:LKPSM, 1996).,h....

7 Santri dapat diklasifikasikan menjadi dua kelompok, yaitu santri mukim dan santri kalong. Santri mukim adalah yang menetap di komplek pesantren. Biasanya santri yang sudah lama menetap (senior) diberi tanggung jawab membimbing dan mengajar adik-adik santri yang lain. Karena tidak semua tugas ditangani kyai, maka perlu ada pendelegasian tugas tersebut kepada yang senior tadi, dewasa, pintar dan bertanggung jawab. Yang kedua santri kalong adalah mereka yang menetap di komplek pesantren (nglaju dalam Bahasa Jawa, atau nyolok dalam Bahasa Madura).Semakin besar sebuah pesantren, maka akan semakin kecil jumlah santri yang nyolok. Dengan kata lain, pesantren kecil akan memiliki lebih banyak santri kalong daripada yang mukim. Uraian tentang santri dan kiyai dapat juga dilihat dalam Zulkifli, Sufism in Java.,h. 3

${ }^{8}$ Lihat Mark R.Woodward, Islam Jawa, Kesalehan Normatif versus kebatinan, terjemahan Hairus Salim AS dari Islam in Java, piety and Mysticism in The Sultanate of Jogjakarta, (Jogjakarta:LKIS, 1999).,h. 6 
masyarakat. Dalam perkembangannya figur ini memiliki kedudukan lebih tinggi dan tak terjangkau bagi komunitas awam karena dianggap memahami keagungan Tuhan dan memahami rahasia alam. ${ }^{9}$ Tiga elemen lain, yaitu masjid sebagai pusat kegiatan santri, asrama serta kitab kuning sebagai materi pelajaran.

Disebut pesantren bila lembaga tersebut memiliki visi, misi dan fungsi kelembagaannya di masyarakat. Ciri khas lain seperti "ruh' atau "jiwa" dan nilai serta tradisi yang mendasari dan meresapi seluruh kegiatan yang dilakukan oleh komunitas pesantren. ${ }^{10}$ Ruh atau jiwa tersebut merupakan salah satu prinsip dari sekian banyak prinsip-prinsip yang harus dipegang dan juga diamalkan, ${ }^{11}$ dilandasi dengan iman, dimotivasi oleh kebersamaan, persatuan danb kesatuan (togetherness and unity) serta berjiwa bebas. Dan nilai-nilai dasar yang dimaksud adalah : nilai-nilai dasar Agama Islam, nilai-nilai budaya bangsa, nilai-nilai dasar pendidikan, nilai-nilai perjuangan dan pengorbanan.

Secara garis besar, pesantren dewasa ini dapat diklompokkan menjadi dua bagian, yaitu: pesantren salaf, seperti Pesantren Lirboyo di Ploso Kediri, Pesantren Maslakul Huda di Pati Jawa Tengah, Pesantren Tremas di Pacitan Jawa Timur dan beberapa pesantren lainnya. Pesantren dengan tipikal salaf umumnya belum tertata rapi secara struktural,namun pengelolannya berpusat pada figur kyai. ${ }^{12}$ Kedua, Pesantrenkhalaf, seperti Pesantren Darussalam gontor Ponorogo, pesantren Walisongo ponorogo, pesantren Al-Amin Prenduan madura, Pesantren Tebuireng Jombang. ${ }^{13}$ Pesantren dengan tipikal khalaf, mulai dari aspek kelembagaan, pengelolaan (manajemen), struktur kurikulum atau bahkan sistem pembelajarannya sudah sama persis dengan sekolah umum. ${ }^{14}$ Falsafah dan

${ }^{9}$ Zamachsyari Dhofier, Tradisi Pesantren; Studi tantang Pandangan Hidup Kyai, (Jakarta: LP3ES, 1982).,h.55

${ }^{10}$ Dawam Raharjo, Pesantren dan.,h.83

${ }^{11}$ Ruh atau jiwa pesantren (di Pondok Moderen Gontor Ponorogo) dirumuskan oleh KH Zarkasyi (salah satu Trimurti pendiri Pondok Moderen Gontor, wafat 1985), dengan istilah "panca Jiwa" terdiri dari jiwa keikhlasan, jiwa kesederhanaan, jiwa ukhuwah Islamiyah, jiwa mandiri dan jiwa kebebasan. Lihat KH Imam Zarkasyi, Diktat KuliahUmum dalam Pekan Perkenalan di KMI Pondok Moderen Darussalam Gontor, 1970.,h.4. Mengenai jiwa ini, juga di Pondok Pesantren nurul Jadid dirumuskan oleh pendirinya KH zaini Mun'im (wafat 1976) dengan istilah "Trilogi Santri" da "Panca Kesadaran "santri. Lihat dalam Masyhur Amin dan M.Nasikh Ridwan, KH Zaini Mun ’im, Pengabdian dan karya Tulisnya, (Jogyakarta: LKPSM, 1996).,h. 169-175

12 Haedari, Transformasi Pesantren.,h. 50

${ }^{13}$ Dhofier, Tradisi Pesantren.,h. 41

${ }^{14}$ Haedari, Transformasi Pesantren.,h.50 
idealisme yang terdiri dari nilai-nilai dasar, jiwa-jiwa dan tradisi-tradisi yang berhubungan dengan tujuan, orientasi, sistem, program dan metode yang dipergunakan dalam melaksanakan nilai sucinya.

Sebesar apapun kelembagaan pesantren,ia harus berpijak pada landasan pendidikan, tujuan pendidikan dan berada dalam bingkai pendidikan. Satu gambaran yang “agak" faktual-operasional dikemukakan oleh Prof. HA. Mukti Ali dalam Imam Bawani sebagai berikut: (1) hubungan santri dan kyai juga para guru yang sam-sama tinggal di satu kompleks pesantren, (2) ketundukan santri kepada kyai dan guru, (3) pola hidup hemat, (4) semangat menolong diri sendiri, (5) persaudaraan yang kuat (Ukhuwah Islamiyah), (7) berani menderita untuk mencapai suatu tujuan ${ }^{15}$; dan keempat, nilai-nilai perjuangan dan pengorbanan.

Sisi lain yang membuat pesantren selalu dikenang dan mempunyai tempat tersendiri di hati masyarakat adalah suasana kehidupan didalamnya yang berbeda dengan suasana di luar pondok pesantren. Suasana kehidupan di pesantren diatur dengan prinsipprinsip hidup "kooperatif dan "self government, yaitu dilakukan dari, oleh dan untuk santri dalam suasana yang harmonis dan penuh kebersamaan. ${ }^{16}$ Pesantren juga merupakan lembaga yang memiliki corak organisasi tersendiri, dimana setiap santri dilatih untuk menjadi pengurus dan kemudian bertanggung jawab terhadap tugas yang diamanatkan kepada dirinya. Pesantren memiliki karakternya sendiri, bersikap independen dari pengaruh-pengaruh dari luar apalagi yang tidak ada hubungannya dengan fungsi kelembagannya.

Hal-hal yang menyatu sebagai unsur-unsur yang dimiliki menunjukkan tentang hakikat kelembagaan pondok pesantren. Secara kultural, pesantren nyaris identik dengan pendidikan tradisional Islam yang memiliki ciri khas yang berbeda dengan budaya sekitarnya. Lembaga ini oleh beberapa peneliti disebut sebagai sub-kultur yang bersifat idiosyncratic. Metode pembelajarannya pun unik, seperti bandongan atau semacam h. $99-100$

${ }^{15}$ Imam Bawani, Tradisionalisme Dalam Pendidikan Islam, (Surabaya; Al Ikhlas. 1993),.

16 Rusydi Sulaiman,dkk, Pondok Pesantren Nurul Jadid: antara Idealisme dan Pragmatisme, (Jember: madania Center, 2004).,h. 32 
collective learning process, sorogan atau semacam individual learning process. ${ }^{17}$ Cukup banyak aspek lain yang memperkuat hakikat pesantren.

\section{Tujuan Pendidikan Pesantren}

Pondok pesantren selanjutnya mesti dikelola dengan baik berdasarkan idealisme pembentukannya. Ia memiliki fungsi ganda, yaitu $(d z u$ wujuh $),{ }^{18}$ yaitu: pertama, sebagai lembaga keagamaan yang berfungsi menyebarluaskan dan mengembangkan ilmu-ilmu keislaman. ${ }^{19}$ Tidak dapat dibayangkan Agama Islam dapat berkembang dan eksis di Indonesia, jika tanpa lembaga seperti pesantren, yang dikenal sangat efektif dalam mengembangkan ilmu pengetahuan. Pondok pesantren merupakan benteng terakhir pertahanan umat Islam Indonesia. Kedua, pesantren berfungsi sebagai lembaga pengkaderan yang telah berhasil mencetak kader umat dan kader bangsa. Pesantren tidak hanya melahirkan alumni yang hanya kompeten dan kredibel dalam ilmu-ilmu agama

17 Amin Haedari, Transformasi Pesantren, Pengembangan Aspek Pendidikan,Keagamaan dan Sosial, (Jakarta: Lekdis dan Media Nusantara, 2006), h.26

${ }^{18}$ Dien Syamsudin, Etika Agama dalam .,h.101.

${ }^{19}$ Ilmu-ilmu keislaman dimaksud adalah ilmu-ilmu yang sumbernya dari al-Qur'an dan Sunnah nabi Muhammad. Beberapa pesantren mendasarkannya kepada pendapat al-Ghazali dalam kitab "Ihya' Ulumiddin" yang menklasifikasikan ilmu menjadi dua bagian, yaitu ilmu akhirat dan ilmu dunia. Pertama, ilmu yang berhubungan dengan al-Qur'an dan Hadits. Kedua, ilmu yang tidak secara langsung bersumber al-Qur'an dan hadits. Ilmu akhirat tersebut lazim disebut ilmu agama dan diklasifikan juga menjadi dua macam: Pertama, ilmu mukasyafah (ilmu yang menyingkap tabir masalah yang ghaib kaitannya dengan masalah ketuhanan, dan hanya dapat ditangkap dengan pengetahuan batin). Kedua, ilmu muamalah, yaitu ilmu yang tujuannya untuk diamalkan. Ilmu tersebut meliputi ilmu syari'ah dan thariqah. Terdapat juga katagori lain tentang ilmu, yaitu ilmu aqliyah dan ilmu naqliyah. Namun beberapa pesantren tidak mengkatagorikan perbedaan ilmu-ilmu tersebut. Menurut mereka ilmu itu adalah art dan science yang dianggap sebagai bagian dari agama. Karena senmata-mata demi kepentingan praksis, maka diklasifikan menjadi ilmu-ilmu yang berhubungan dengan aqidah, syari'ah dan ilmu pelengkap. Pendekatan yang dgiunakan lebih kepada penggunaan logika murni dengan penghayatan yang melibatkan perasaan daripada metode empirik dan eksperimen obyektif. Cara nalarnya lebih bersifat deduktif daripada induktif atau menggunakan metode ilmiah lainnya. Ilmu-ilmu di pesantren lebih bersifat normatif daripada nomotetik dan derkriptif (menurut Amin Abdullah bersifat historis), sehingga sedikit banyak berbeda dengan konsep ilmu umum terutama ilmu kealaman. Sebenarnya faktor-faktor di luar akal fikir, metode ilmiah maupun eksperimen terdapat cara bagaimana suatu pengetahuan diperoleh, yaitu apa yang lazim disebut ilham, hidayah dan hikamah dari Allah SWT. KH Hasan Abdul Wafi menyebutkan terdapat tiga klasifikasi ilmu, yaitu; Pertama, ilmu fardlu 'ain meliputi aqidah, syari'ah dan akhlak. Kedua, Ilmu fardlu kifayah, yaitu sebuah disiplin ilmu yang apabila tidak ada yang mempelajarinya akan menimbulkan mafsadah 'ammah, seperti ilmu kedokteran, pertanian, ketetanegaraan danlainlain. Ketiga, Ilmu masnun, yaitu ilmu pelengkap/ kelengkapan hidup, bila ditinggalkan tidak menimbulkan mafsadah, seperti ilmu tata rias, ilmu tata ruang dan lain-lain. Lihat KH Hasan Abdul Wafi, Wawasan Pendidikan Pesantren, Makalah dalam Semiloka Kependidikan, tgl. 8-9 Agustus 1991 di Pondok Pesantren Nurul Jadid Probolinggo Jawa Timur. 
( aqiih $f i$ al-Diin), tetapi tidak sedikit yang telah mampu menjadi pemimpin atau elit strategis dalam berbagai bidang kehidupan.

Pendapat lain yang dikemukakan oleh M. Arifin pada dasarnya tujuan kelembagaannya terbagi menjadi dua hal, yaitu tujuan umum dan tujuan khusus. Tujuan khusus adalah mempersiapkan para santri untuk menjadi orang yang alim dalam ilmu agama dibawah bimbingan seorang kyai serta mengamalkan ilmu-ilmu tersebut di tengah masyarakat. Sedangkan tujuan umumnya adalah membimbing anak didik untuk menjadi manusia yang berkepribadian Islam yang dengan bekal ilmu agamanya dapat disiapkan menjadi mubaligh Islam..$^{20}$ Diharapkan alumni-alumni pesantren menjadi generasi yang dapat berkiprah di tengah masyarakat.

Untuk memperkuat kelembagaan pondok pesantren dalam melaksanakan tugas keagamaannya, lembaga ini harus memiliki tiga fungsi, yaitu: pertama, pesantren sebagai lembaga pendidikan dan pengajaran ;Kedua, pesantren sebagai lembaga pelayanan, pengarahan dan pembimbingan masyarakat; Ketiga, pesantren sebagai lembaga perjuangan. ${ }^{21}$ Pesantren juga berperan sebagai benteng pertahanan dan pusat penyebaran Islam. $^{22}$

Untuk melaksanakan fungsinya, pondok pesantren membuat program dan jenis pendidikan secara terpadu sepanjang tahun dan tetap memperhatikan agenda dan prioritas kerja yang telah disusun sebelumnya, yaitu pendidikan keimanan dan ketaqwaan, pendidikan akhlaqul karimah, pendidikan kewarganegaraan dan kemasyarakatan, pendidikan keilmuan dan intelektualitas, pendidikan kepemimpinan, organisasi dan manajemen, pendidikan keguruan, pendidikan kewirausahaan dan keterampilan, pendidikan olah raga adan kesehatan, dan beberapa jenis pendidikan lainnya. ${ }^{23}$

${ }^{20}$ Rohadi Abdul Fatah, dkk, Rekonstruksi Pesantren Masa Depan (dari tradisional modern, hingga post modern, (Jakarta: PT. Listafariska Putra, 2005), cet.1,. h. 20.

${ }^{21}$ Hasan Abdul Wafi, Wawasan.,h. 2

22 Zulkifli, Sufism in Java: The Role of .,h. 1

23 Salah satu pesantren di Jawa Timur, yaitu Pondok Pesantren Nurul Jadid juga mengembangkan jenis-jenis pendidikan sebagaimana tersebut diatas. Agar fungsi lembaga pesantren lebih maksimal dan sistematis serta relatif lebih mudah dalam mengukur keberhasilan, maka disusun misi pesantren sebagai berikut: Pertama, Pengembangan keimanan dan ketaqwaan kepada Allah SWT serta pembinaan akhlaqul karimah. Kedua, pengembangan pendidikan, keilmuan dan wawasan. Ketiga, pengembangan minat dan bakat. Keempat, pembinaan keterampilan dan keahlian. Kelima, pengembangan kewirausahaan dan kemandirian, Keenam, penanaman kesadaran hidup sehat dan kepedulian terhadap lingkungan, Dan ketujuh, peananaman tanggung jawab kemasyarakatan dan kebangsaan. Lihat dalam M.Masyhur Amin,dkk, KH Zaini Mun'im, 
Sekali lagi bahwa pesantren tetap memiliki fungsi-fungsi sebagai: pertama, lembaga pendidikan yang melakukan transfer ilmu-ilmu agama (tafaqquh fi al-Din) dan nilai-nilai Islam (Islamic values). Kedua, lembaga keagamaan yang melakukan kontrol sosial (social control), dan ketiga, lembaga keagamaan yang melakukan rekayasa sosial (social engineering). ${ }^{24}$ Dengan demikian bahwa pondok pesantren bisa dijadikan sebagai lembaga pendidikan Islam yang dipergunakan untuk penyebaran agama dan tempat mempelajari agama Islam khususnya.

Dapat disimpulkan dari beberapa pendapat diatas, bahwa tujuan pondok pesantren adalah membentuk kepribadian Muslim, dimana Muslim yang menguasai ajaran-ajaran Islam dan mengamalkannya, sehingga bermanfaat dan diamalkan bagi agama, masyarakat dan negara.

\section{Falsafah dan Idealisme}

Apapun fungsi kelembagaan pesantren, lembaga tersebut mesti dilandasi dengan falsafah dan idealisme yang kuat. Fungsi-fungsi tersebut diharapkan menjadi basis dan tujuan pengembangan pesantren tersebut agar tetap bertahan dan tidak terombang ambing di telan zaman. Adapun falsafah dan idealisme tersebut terdiri dari nilai-nilai dasar, jiwajiwa dan tradisi kepsantrenan .

\section{Nilai-nilai Dasar}

\section{a. Nilai-nilai dasar Agama Islam.}

Apapun bentuk aktifitas yang ada di pondok pesantren harus mengacu dan merujuk pada nilai-nilai dasar pesantren yang sumber primernya adalah wahyu, alQur'an dan Hadits, dan tercermin dalam aqidah, syari'ah dan akhlaq. Cerminancerminan tersebut dipandang oleh ulama pewaris nabi (al-Ulamaa' Waraatsat alAnbiyaa'), utamanya ulama salaf, dapat dipertanggungjawabkan dan memiliki tingkatan keilmuan yang tinggi. Motivasi dan niat utama para pengasuh dan para santri senantiasa timbul dan bergerak dari rasa keterpanggilan dan tanggung jawab

Pengabdian.,h. 141. Juga lihat Humas Koordinatorat dan BPPM NJ, Profil Pondok Pesantren Nurul Jadid, (Probolinggo, 2004

${ }^{24}$ Haedari, Transformasi Pesantren.,h. 32 
(sense of responsibility) untuk berdakwah sebagai kelanjutan dari rasa memiliki (sense of belonging) terhadap risalah Rasulullah.

\section{b. Nilai-Nilai Budaya Bangsa.}

Implementasi nilai-nilai dasar Islam harus selalu disesuaikan secara harmonis dan akomodatif dengan kultur, tradisi dan budaya lokal serta bangsa Indonesia secara umum tanpa harus menafikan prinsip-prinsip dasar pesantren. Proses ini disebut oleh Gus Dur (panggilan Abdurrahman Wahid) dengan istilah "pribumisasi" Islam yaitu melakukan pelenturan terhadap budaya dan kultur lokal seperti yang telah dilakukan oleh walisongo (sembilan ulama penyebar agama Islam di Pulau Jawa. Dengan demikian, pesantren sebagai lembaga sosial akan cepat dikenal, mendapat respon positif dan memperoleh pengakuan sosial (social recognition) yang luas. ${ }^{25}$

\section{c. Nilai-Nilai Dasar Pendidikan.}

Sejak awal pembentukannya, pondok pesantren memiliki tugas mendirikan pendidikan dan pengajaran kepada umat agar menjadi umat terbaik, yaitu berkualitas dan bermanfaat bagi masyarakat luas ecara imaniah, ilmiah dan amaliah, "Khair al-Naas 'Anfa'uhum li al-Naas". Alumni pesantren diharapkan dapat menjadi pelaku dakwah Islam dan penerus risalah Rasulullah di tengah masyarakat. Apapun yang dilakukan harus berpijak pada landasan pendidikan, tujuan-tujuan pendidikan dan berada dalam bingkai pendidikan. Para santri menganggap bahwa menentang kiyai selain tidak sopan, juga dilarang oleh ajaran agama; ketiga, pola hidup hemat dan sederhana; keempat, semangat menolong diri sendiri. Para santri mencuci pakain sendiri, membersihkan kamar tidurnya sendiri, bahkan tidak sedikit yang memasak makanan sendiri; kelima, jiwa tolong menolong dan suasana persaudaraan yang disebabkan oleh selain kehidupan yang merata di kalangan santri, juga karena mereka harus mengerjakan pekerjaan yang sama, seperti shalat jama'ah, membersihkan masjid dan ruang belajar secara bersama; keenam, disiplin. Pagi-pagi antara jam 3.30 atau 4.00, pengasuh/ kyai telah membangunkan para santri untuk diajak shalat subuh berjama'ah; ketujuh, berani menderita untuk mencapai satu tujuan. Mereka terbiasa tirakat (Riyadhah),

${ }^{25}$ Dien Syamsudin, Etika Membangun.,h. 102 
baik dengan puasa sunnat, shalat tahajjud, i’tikaf di masjid untuk merenungkan kebesaran Allah dan bentuk amalan yang lain. ${ }^{26}$

\section{d. Nilai-Nilai Perjuangan dan Pengorbanan}

Komunitas pesantren harus menyadari bahwa tugas mereka di pondok pesantren semata-mata perjuangan besar yang membutuhkan pengorbanan, lahir dan batin. Tugas dan jabatan adalah amanat Allah yang harus dipertanggungjawabkan dengan penuh sikap ikhlas. Adapun apresiasi pesantren berupa honorarium, bukan semata-mata tujuan hidup, apalagi mencari kepentingan duniawi (bussiness oriented).

\section{E. Jiwa-Jiwa Kepesantrenan}

Kehidupan di pesantren harus diwarnai oleh suasana yang tersimpul dalam apa yang disebut dengan jiwa-jiwa kepesantrenan. Jiwa-jiwa yang diharapkan dapat mewarnai dan mengendalikan kehidupan komunitas pesantren tersebut adalah sebagai berikut:

Pertama, Besrikap ikhlas, yaitu sikap yang tulus tanpa tendensi dan ditujukan hanya kepada Allah SWT. Jiwa ini merupakan cerminan dari tauhid dan aqidah yang kokoh. Hidup dipandang sebagai ibadah, ajaran dari guru agama yang tidak dapat dibantah lagi karena ajaran ini merupakan bagian dari ibadah; cinta terhadap doktrin Islam; dedikasi pada masalah agama dan kesinambungan masalah santri. ${ }^{27}$ Kedua, Hidup sederhana, yaitu merupakan refleksi dari sifat dan sikap zuhud, wara' dan qona'ah dalam pengertian yang benar dan proporsional. Sederhana bukan berarti miskin.

Ketiga, Berjiwa mandiri, berarti tidak menggantungkan diri kepada orang lain, tapi memiliki keperibadian yang utuh dan ideal serta percaya diri (self confidence), Keempat, Ukhuwah Islamiyah yang dilandasi dengan iman, dimotivasi oleh kebersamaan, persatuan danb kesatuan (togetherness and unity). Kelima, Berjiwa bebas, dalam artian merdeka dan bebas berpikir, bebas menentukan sikap. Tentu atas dasar iman, ilmu dan akhlaqul karimah.

\section{$99-100$}

${ }^{26}$ Imam Bawani, Tradisionalisme dalam Pendidikan Islam, (Surabaya, al-Ikhlas, 1993).,h.

27 Pradjarta Dirjosanjoto, Memelihara Umat: Kiyai Pesantren-Kiyai Langgar di Jawa, (Jogjakarta: LkiS, 1999).,h.141 Lihat juga Abdurrahman Wahid, Menggerakkan Tradisi: Esai-Esai Pesantren, (Jogjakarta: LkiS, 2001) 
Prinsip-prinsip tersebut yang membedakan pesantren daripada lembaga lain. Pesantren Nurul Jadid menggunakan istilah trilogi pendidikan, yaitu: al-Ihtimam bi alFuruudh al-'Ainiyah, al-Ihtimaam bi Tarki al-Kabaair, dan Husn al-Adab ma'a Allah wa ma'a al-Khalq. ${ }^{28}$ Dan panca kesadaran, yaitu: (al-Wa 'iyyaat al-Khamsu) ${ }^{29}$ adalah: alWa'yu al-Diiniy, al-Wa'yu al-'Ilmiy, al-Wa'yu al-Hukuumy wa al-Sya'biy, al-Wa'yu alIjtimaa'iy, dan al-Wa'yu al-Nizhaamiy.

\section{F. Tradisi Kepesantrenan}

Sisi lain yang dapat membuat pesantren selalu dikenang dan mempunyai tempat tersendiri di hati masyarakat adalah suasana kehidupan di dalamnya yang menarik dan unik. Nuansa khusus tersebut telah menjadi tradisi dan rutinitas, baik yang berkaitan dengan masalah hubungan manusia dengan Allah (Mu'aamalah Ma'a al-Khaaliq) dan hubungan interaktif sesama manusia (Mu'aamalah Ma'a al-Khalq) yang tetap mengacu pada nilai-nilai dasar dan jiwa-jiwa kepesantrenan.

Kehidupan di lingkungan pesantren idealnya diatur atas dasar prinsip-prinsip hidup "kooperatif" dan "self government", segalanya berjalan atau dilakukan dari, oleh dan untuk santri dalam suasana yang harmonis, penuh kasih sayang dan penuh kebersamaan. Pola atau bentuk hubungan antar individu di lingkungan pesantren; antara kyai dan santri, kyai dengan wali sanri, kyai dengan ustadz, kyai dengan pengurus pesantren dan sebaliknya, antara sesama santri, keluarga pesantren dengan masyarakat luar-di laksanakan atas dasar "Al-Ishlaah wa al-Mashlahah", Lahu Wa'alaih, Take and Give" dalam suasana "Fastabiq al-Khairaat" menuju kebaikan dalam rangka meraih prestasi setinggi-tingginya.

Prinsip-prinsip tersebut tidak hanya/sekedar atau dijadikan slogan/simbol atau uraian-uraian teoritik saja, tapi benar-benar diimplementasikan dalam bentuk tradisi atau sunnah yang berlaku di sebuah pondok pesantren.

${ }^{28}$ Lihat Humas Koordinatorat dan BPPM NJ, Profil.,h. viii

${ }^{29} \mathrm{KH}$ Wahid Zaini, Paradigma Pendidikan Pesantren dalam Meningkatkan Kualitas Sumber Daya Insani, Makalah dalam Dialog Pesantren, Diselenggarakan oleh Alumni Pondok Pesantren Sunan Drajat Banjaranyar Paciran Lamongan, tgl. 20 Juni 1994 


\section{G. Prinsip Memelihara dan Mengakomodasi}

Ketika sebuah pesantren dianggap sebagai lembaga yang kuat secara kelembagaan dari pengaruh apapun diluar dirinya, namun ia tetap harus waspada. Dua sikap fleksibel yang mesti melekat setidaknya adalah prinsip memelihara dan juga mengakomodasi. Muslim Abdurrahman menyebutnya: prinsip konservasi dan akomodasi ${ }^{30}$

Prinsip akomodasi dan konservasi memberi makna bersikap inovatif dan terbuka (welcome) terhadap berbagai ide baru yang ashlah, lebih shalih selama tidak menyentuh hal-hal yang sangat prinsip. Nilai dasar, tradisi kepesantrenan dipertahankan. Asapun metode, sistem, atau kurikulum yang lebih shalih juga perlu diadopsi. Prinsip tersebut adalah:" al Muhaafadzah ala al-Qadiim al-Shaalih wa al- Akhdzu bi al- Jadiid al-Ashlah (mempertahankan hal-hal lama yang baik dan mengambil sesuatu yang baru yang lebih baik).

\section{H. Fenomena Pesantren di Kep. Bangka Belitung}

Dimaklumi bahwa tidak begitu banyak jumlah pesantren di Kep. Bangka Belitung, apalagi yang usianya cukup tua. Regenerasi menjadi salah satu faktor lemahnya kelembagaan pesantren. Beberapa pesantren yang ada di wilayah ini masih relatif muda dan akar kepesantrenannya pun belum jelas. Hampir-hampir keberadaannya secara umum bertolak belakang dengan filosofi pembentukan pesantren awal.

Sedikit sekali literatur khususnya hasil penelitian yang mengindikasikan hal tersebut. Namun demikian, ditemukan beberapa literatur yang menulis tentang Pondok Pesantren, misalnya: tulisan Zulkifli tentang: "Kontinuitas Islam di Bangka" adalah hasil penelitian yang secara spesifik membahas tentang model pendidikan di Mendobarat termasuk al-Islam yang terletak di Desa Kemuja (tahun 1997). Selanjutnya karya penulis (Rusydi Sulaiman) tentang Pondok Pesantren al-Islam; sejarah, aspek pendidikan dan manajemen kelembagaannya (2016). Karya lain adalah dalam bentuk profil beberapa pesantren, namun sangat sederhana dan tidak dipublikasikan.

Tak terbantahkan bahwa pesantren merupakan lembaga pendidikan islam yang juga mengawali proses pendidikan di Pulau Bangka. Semangat tersebut tak telepas dari kelanjutan dari gagasan ulama setempat yang pernah mukim dan menempuh ilmu di timur

\section{3.,h. 50}

${ }^{30}$ lihat Muslim Abdurrahman, Islam Transformatif, Jakarta: Pustaka Firdaus, 1997), Cet 
tengah. Al-Islam Kemuja misalnya sebuah pesantren yang digagas pendiriannya pada tahun 1930-an Masehi, berawal dari pengajian-pengajian dari rumah ke rumah dengan cara mendatangi kediaman tokoh-tokoh tertentu yang disebut sebagai guru atau tuan guru $^{31}$. Terdapat sekitar tigapuluh murid yang belajar dengan sarana prasarana dan fasilitas yang memadai di sebuah sekolah Arab sebagai cikal bakal Pondok Pesantren al-Islam Kemuja. $^{32}$ Guru Zaman menambahkan, bahwa tidak kurang dari enampuluh santri yang belajar di tiga kelas pada sore hari, mulai jam $13.30 \mathrm{sd}$. 17.00 Wib., diselang dengan masa jeda tigapuluh menit untuk Shalat Ashar berjamaah. Besar harapan santri untuk mendalami ilmu agama, sehingga setelah itu berdiri empat institusi, yaitu: Madrasah Diniyah, Madrasah Ibtidaiyah, madrasah Tsanawiyah dan Madrasah Aliyah. ${ }^{33}$ Berikutnya dibangun beberapa sarana prasarana pondok pesantren seperti mushalla putra dan mushalla putri dan beberapa gedung asrama santri. Secara historis, konsep pesantren muncul belakangan pasca pendirian masjid dan madrasah.

Beberapa lembaga tua lainnya yang bermunculan di awal abad keduapuluh masehi di kepulauan ini adalah Pondok Pesantren Nurul Ihsan Baturusa, Pondok Pesantren Darussalam yang juga sebenarnya berawal dari madrasah atau sekolah Arab. Beberapa ulama cenderung bergerak secara individual dalam bentuk pengajian kitab tertentu tentang ilmu agama Islam dasar, dan kemudian diminati oleh komunitas tertentu. Setelah itu muncul beberapa pesantren sebagai kelanjutan pesantren di Pulau Jawa dan kalimantan

${ }^{31}$ Masyarakat Kemuja menamakan mereka yang pernah mukim atau tinggal di Makkah untuk beberapa tahun dengan istilah orang yang naon. Kemudian sebagian dari mereka mengajarkan ilmu agama di kediamannya masing-masing. Adapun beberapa diantara mereka memiliki kontribusi dalam proses pendirian pondok pesantren al-Islkan hasil wawancara dengan bapak Zuryaden, Pimpinan podok pesantren al-Islam bahwa menyatakan tokoh-tokoh yang mukim di Makkah dan kembali ke kampung halaman adalah H. Abdurrasyid (Akek Dor), H,Adam, H.Yunus, H.Derasak (periode pertama). Setelah itu menyusul beberapa orang termasuk H.Abdus Somad. Akek Dor dan H.Adam yang menggagas pembangunan Sekolah Agama di Desa Kemuja (Berdasarkan catatan Guru Imron bin H.Dja'far). Berkaitan dengan semangat pendirian Pondok Pesantren al-Islam, disebutlah beberapa tokoh kharismatik lainnya, antara lain: H.Ahmad bin H. Abu Bakar, H. Ahmad bin H. Ladi, H.Azhari, H. Mahrob bin H. Aban, H. Sanusi bin H. Aban, H. Junaidi bin H. Mad Amin, H. Jemain (Atok Tarmizi, Bupati Bangka Induk), H. Usman, H. Abdul Latif. Tidak semua tokoh-tokoh tersebut menjadi guru di sekolah arab sebagai cikal bakal pondok pesantren al-Islam. Wawancara dengan Ustadz Zaman di kediamannya Bukit Marapin Pangkapinang, Kamis 15 Oktober 2015.

${ }^{32}$ Zulkifli, Kontimuitas Islam Tradisional di Bangka, (Bangka, Siddiq Press, 2007).,h.56

${ }^{33}$ Zaman, Kisah Berdirinya Pondok Pesantren al-Islam (belum diterbitkan), Maret 2003) 
karena beberapa putra daerah yang merintisnya atau gagasan ulama pendatang. Pesantrenpesantren tersebut memiliki karakternya sendiri-sendiri tergantung kekuatan falsafah dan idealisme serta arah afiliasinya.

Pondok pesantren di kepulauan ini sepertinya sebatas merepresentasikan masyarakat menengah kebawah-bertolak belakang dengan sekolah umum dan sekolah kristiani yang pangsa pasarnya lebih tinggi. Kelembagaan pesantren yang terlalu "barbau agama" dalam pengertian normatif dan pola pengembangannya yang stagnan nampaknya belum menjadi daya tarik tersendiri bagi masyarakat yang cenderung pragmatis. Diharapkan ada terobosan tertentu dalam mengelola pondok pesantren, setidaknya untuk kepentingan penguatan Agama Islam di Kep. Bangka Belitung.

\section{Al-Islam Kemuja: Penguatan kelembagaan Pesantren}

Sebagaimana diurai bahwa Pondok Pesantren al-Islam adalah salah satu lembaga pendidikan tradisional Islam yang muncul dan berkembang di Kepulauan Bangka Belitung tepatnya di desa Kemuja. Pesantren tersebut tidak muncul begitu saja melainkan didasari atas perjuangan dan pengorbanan para pendahulu di desa tersebut. Satu hal yang membedakan lembaga ini dengan beberapa pondok pesantren di Kepulau Bangka Belitung adalah aspek Falsafah dan Idealisme yang secara spesifik berkenaan dengan jiwa, nilainilai dan tradisi kepesantrenan yang berlangsung lama didalamnya.

Walaupun tidak terlalu maju, namun Pondok Pesantren al-Islam Kemuja mampu mempertahankan eksistensinya hingga saat ini. ${ }^{34}$ Paling tidak idealisme pendiriannya memberi pengaruh terhadap kelembagaannya. Hal tersebut dirumuskan untuk mempertegas komitmen awal pendirian Pondok Pesantren al-Islam dan sebagai pijakan bagi pengurus yayasan dalam menentukan kebijakan tertentu. ${ }^{35}$

Bila ditelusuri akar kelembagaannya Pondok Pesantren al-Islam hampir sama proses pembentukannya dengan beberapa pesantren di Pulau Jawa, yaitu berawal dari

${ }^{34}$ Beberapa hal terkait hal tersebut digambarkan oleh Ust. Nusro: pertama, Pon Pes alIslam dari masa ke masa mampu berpacu dalam menciptakan kondisi yang kondusif dalam menghadapi arus globalisasi; kedua, sekian ribu alumnus Pondok Pesantren al-Islam tersebar di sebagian besar pelosok tanah air sebagai abdi masyarakat dan abdi negara; ketiga, pasang surutnya ekonomi masyarakat bukan menjadi kendala bagi mereka untuk mendidik putra putrinya ke pon Pes al-Islam Kemuja; keempat, secara kuantitatif Pondok Pesantren al-Islam masih tetap berkibar di Kepulauan Bangka Belitung. Wawancara denga Ust.Nusro, Senin, tgl. 24 Agustus 2015

${ }^{35}$ Wawancara dengan Ust. Sopian, Ahad, tgl. 27 September 2015 
adanya tokoh-tokoh tertentu yang sangat kharismatik yang memiliki banyak murid yang berguru kepada mereka. Di jawa umumnya, pembentukan pesantren berawal dari inisiatif seseorang yang kemudian dipanggil kyai/ pengasuh karena perjuangan dan pengorbanannya membabat lahan hutan yang kemudian dijadikan basis pesantren. Di Kemuja, terdapat beberapa guru atau kyai yang didatangi para murid. Tokoh-tokoh tersebut bersikap pasif saja karena inisiatif mengaji muncul dari para murid. Guru-guru kompeten di bidang tertentu yaitu pengetahuan ke-Islaman dasar. Mereka bertahun tahun mukim di Makkah untuk mendalami ilmu agama pasca ibadah haji.

Hubungan guru-murid berlangsung dalam bentuk pengajian kitab-kitab dasar disebut, kitab Kuning, seperti materi pelajaran (Fikih, Tauhid dan Akhlaq), dimana si murid mendatangi guru sebagai figur- sentral di masyarakat. Di desa Kemuja pangajian bermula di daerah Katon (di rumah kosong Akek Umar) kemudian pindah ke rumah Amang Aser (P.H.Tajo,1948-1952). Cukup banyak pengetahuan dan prinsip hidup yang diajarkan kepada murid-murid bahkan mereka juga mengabdi kepada guru; membantu di kebun, dirumah "meringankan beban guru dalam situasi ekonomi yang sangat sulit saat itu". ${ }^{36}$ Belum ditemukan saat itu sebuah masjid yang cukup memadai untuk menampung beberapa kegiatan pengajian. Proses pembelajaran dilakukan sendiri-sendiri di kediaman masing-masing guru/ kyai.

Di desa Kemuja, berdirilah sebuah masjid kampung. Masjid merupakan milik kampung dan digunakan seluruh masyarakat kampung sebatas kegiatan ibadah rutin keagamaan, bukan untuk pengajian kitab kuning sebagaimana yang dilakukan di rumahrumah guru. Hampir tidak ada kaitan materi kitab kuning guru/ kyai satu dan kyai lainnya. Namun kemudian ada semangat beberapa murid dan kyai-kyai tertentu untuk menyatukan materi pelajaran dalam satu lembaga tertentu. Secara de facto, pesantren ala Jawa sudah berlangsung di Desa Kemuja, karena sudah ada dua unsur, yaitu guru dan murid serta ada juga materi yang diajarkan. Hanya saja ide menyatukan kegiatan tersebut di satu lingkungan dengan masjid sebagai sentral kegiatan dan satu kyai yang difigurkan baru muncul belakangan. Di Kemuja, bangunan sekolah Arab mendahului pembangunan asrama santri. Ide pesantren terinspirasi dari pengalaman gagasan pesantren di luar Pulau Bangka.

\footnotetext{
${ }^{36}$ Wawancara dengan Bapak Guru Zaman, Kamis 15 Oktober 2015, di Kediaman beliau di Bukit Marapin.
} 
Di sekitar tahun 1955, berdirilah Madarasah pertama yang dinamakan dengan Madrasah Diniyyah yang kala itu masyarakat Kemuja menyebutnya sekolah Arab. Sekolah Arab ini didirikan atas swadaya masyarakat desa Kemuja dengan bergotong royong mencari kayu dan mengumpulkan material bangunan lainnya. Hingga sekarang bangunan kayu dua lantai yang berada di tengah tengah desa Kemuja tersebut masih dapat dipergunakan untuk ruang belajar Taman Pendidikan Alquran (TPA) Al-Islam. ${ }^{37}$ Beberapa tahapan kegiatan pembangunan gedung madrasah, yaitu tahap 1 tahun 1950 sd. 1956, pembangunan madrasah diawali dengan sosialisasi dan ajakan kepada masyarakat untuk berkorban membangun madrasah, tahap II berlangsung dari tahun 1957 hingga 1963, dan tahap III, pembangunan madrasah berlangsung dari tahun 1964 sd. 1967. ${ }^{38}$ Gedung itu disebut sekolah tingkat.

Pada tahun 1968 berdiri Madrasah Ibtidaiyyah (MI) yang kurikulumnya berafialisasi ke Kementerian Agama (sebelumnya disebut Departemen Agama). Madrasah yang berbasis kurikulum Depag ini semula diberi nama Madrasah Ibtidaiyyah Al-Khairiyah atau MIPN (Madrasah Ibtidaiyyah Persiapan Negeri ). Pendirian Madarasah Ibtidayyah ini atas inisiatif dari tokoh agama desa Kemuja yakni Ilyas Ya'kub yang juga saat itu berstatus sebagai Pegawai Negeri Sipil Kementerian Agama (menetap di Toboali, Bangka Selatan). Madarasah Ibtidaiyyah didirikan dengan maksud memfasilitasi putra putri desa Kemuja agar dapat memperoleh ijazah setelah mereka tamat dan dapat meneruskan pendidikan ke jenjang berikutnya. Disamping itu, keberadaan MI dibutuhkan untuk melengkapi Madrasah Diniyyah yang sudah berdiri sebelumnya. ${ }^{39}$

Pada tahun 1976 berdirilah Madarasah Tsanawiyah. Madrasah ini dimaksudkan untuk menampung mereka yang sudah menamatkan pendidikan di Madarasah Ibtidaiyyah dan sekolah Dasar. Santri-santri yang belajar/mondok di Pondok Pesantren al-Islam dan menjadi siswa di Madrasah Tsanawiyah tidak hanya putra putri yang berasal dari desa

${ }^{37}$ Sebelum terbentuknya sekolah arab, sudah berlansung kegiatan pengajian dikediaman para guru yang bermula di Desa Katon pindah ke kampung Baru sekitar tahun 1940 an. Diantara murid-murid yang pernah berguru di sekolah Arab tersebut adalah Umar, Tajo, Sulaimana, Bujut, Abdul Hadi, Muhtak bin H. Mufti, Humasi, Zaman, Sofwan, Musdar. Tidak mudah menjadi murid di sekolah Arab tersebut karena harus diseleksi, membaca al-quran dan menulis arab. Adapun materi pelajaran saat itu tauhiq dan fiqih (ilmu ibadah dan amalan). Wawancara dengan Ustadz Zaman Kamis, 15 Oktober 2015.

${ }^{38}$ Zaman, Kisah berdirinya....

${ }^{39}$ Dokumen yayasan pondok pesantren al-Islam Kemuja (2013) 
Kemuja, melainkan juga berdatangan dari desa-desa sekitar bahkan berasal dari desa-desa yang cukup jauh jaraknya dari kecamatan Mendobarat.

Setelah berdiri Madrasah Tsanawiyah, sejak itu terbentuklah kepengurusan Pondok Pesantren secara formal. Momentum kedatangan Drs.H.Sanusi (Kabid Pergurais Kanwil Agama Sumatera Selatan ke Kemuja tgl. 25Mei 1976 (malam 17 Ramadhan) di kediaman H.Saat (Tajo) dijadikan dasar pembentukan PPAI. ${ }^{40}$ Selang bebrapa tahun, tepatnya tahun 1982 pengurus Pondok Pesantren mendirikan Madarasah Aliyah (MA) yang bertujuan menyediakan wadah pendidikan bagi mereka yang sudah menamatkan Madrasah Tsanawiyah. Dengan berdirinya Madarasah Aliyah diharapkan masyarakat Desa Kemuja dapat melanjutkan pendidikan putra putri mereka ke jenjang yang lebih tinggi. Perlu diketahui bahwa untuk tingkat SLTA saat itu hanya ada di kota Pangkalpinang. Jumlah Madrasah yang benar-benar fokus mengkaji materi keagamaan sangat ssedikit. Pada tahun 1990, berdiri pula Taman Pendidikan Alquran (TPA) yang dipelopori oleh Drs. Ahmad Tafzani.

Berturut-turut yayasan pondok pesantren al-Islam diketuai oleh Drs M.Fuad Ahmad selaku Pjs pimpinan. Selanjutnya Guru Dahlan bin H.Mat Yasin, Guru Umar, Guru Dahlan, Ustadz Zulyaden, Sulaiman H. Achamad, dan Drs. Amzahri (sejak tahun 2007 hingga sekarang). Secara struktural, kepemimpinan tertinggi berada di tangan yayasan, membawahi pimpinan pesantren. Dibandingkan dengan sebelumnya, situasi pondok pesantren saat ini lebih kondusif. Terkadang pengurus pesantren sulit menolak calon guru yang ingin mengabdikan diri mereka di beberapa sekolah di lingkungan Yayasan pondok Pesantren al-Islam.

Pada saat awal berdirinya, dukungan masyarakat terutama warga pengikut ahlussunnah waljamaah dari kelompok Nahdliyyin sangat besar. Hal tersebut tentunya menjadi modal dasar bagi pengembangan kelembagaan Pondok Pesantren Al-Islam. Beberapa bidang dibawahnya sesuai kebutuhan yayasan, seperti bidang kepesantrenan, ekonmi, pendidikan, dan bidang pembangunan serta sarana prasarana. ${ }^{41}$

${ }^{40}$ Beberapa tokoh yang hadir dalam deklarasi tersebut adalah: H.Saat, H.Nashruddin (Kades Kemuja), Guru Imron bin H. Dja'far (Madrasah Diniyah), Guru Zaman Zahri (Madrasah Tsanawiyah), H.Junaidi (penghulu), Drs.M. Fuad Ahmad, Humasi dan H. Rozali Saat (catatan Kecil Guru H,Imron bin H, Dja'far).

${ }^{41}$ Dokumen Yayasan Pondok Pesantren al-Islam Kemuja (2013) 
Pendirian lembaga Pondok Pesantren didorong oleh kemauan keras dan tekad kuat serta semangat memberikan pelayanan pendidikan khususnya pendidikan Agama Islam bagi para putra putri desa Kemuja khususnya dan Pulau Bangka umumnya. Cukup tinggi antusiasme masyarakat, terlebihb pada saat itu belum banyak sarana pendidikan seperti saat ini di kep. Bangka Belitung. Hanya terdapat beberapa lembaga Pendidikan setingkat sekolah dasar (SDN) di desa-desa sekitar. Dan tidak semua kecamatan di wilayah Bangka Belitung memiliki lembaga pendidikan setingkat SLTP dan SLTA. Kehadiran Pondok Pesantren Al-Islam dirasakan sangat membantu bagi terpenuhinya kebutuhan masyarakat akan pendidikan untuk mencerdaskan anak-anak mereka.

Dalam prosesnya, nuansa kepesantrenan menurun. Apa yang dilakukan di sekolah lebih efektif daripada di asrama, bahkan materi pelajaran Kitab Kuning pun diajarkan dengan sistem klasikal, dimana tidak ada lagi sistem sorogan, bandongan dan wetonan layaknya pesantren salaf. Terlebih para ustadznya tidak lagi bersarung, tapi memakai celana panjang dalam mengajar. Bahkan kenyataannya mereka lebih senang mengajar di sekolah formal daripada membina santri di asrama pesantren. Namun demikian satu ciri khas yang tidak pernah ditinggalkan hingga saat ini adalah kopiah/ songkok. Dalam budaya pesantren bila berkopiah, maka seorang guru dipanggil ustadz atau kyai, sebaliknya bila tidak, dipanggil pak guru saja. ${ }^{42}$ Situasi demikian memicu semangat para pengurus yayasan untuk mengintensifkan kembali materi pelajaran salafiyah di asrama mengembalikan memori masyarakat bahwa cikal bakal Pondok Pesantren al-Islam adalah pendidikan tradisional, yaitu Pesantren Salafiyah. Menurut Zuryaden, pimpinan pesantren basis teologis pesantren ini dan masyarakat sekitar adalah Ahlus-Sunnah Wal-Jama'ah. ${ }^{43}$ Satu motto yang dimiliki teologi tersebut adalah al-Muhaafadzah 'ala al-Qadiim al-

${ }^{4242}$ Di Kep. Bangka Belitung umumnya sebutan untuk orang dianggap sangat kompeten dalam bidang ilmu agama Islam adalah guru - tuan guru sebagaimana di daerah lombok dan sekitarnya, istilah kyai di Jawa, istilah buya di sebagian sumatra. Guru dimaksud adalah benar-benar guru untuk komunitas tertentu, tidak hanya agama melainkan teladan dalam bidang akhlak mulia. Guru dimaksud bukanlah pak guru atau bu guru di sekolah formal. Panggilan untuk guru agama belakangan ini berubah menjadi ustadz dan kyai menggantikan sebutan guru. Kenyataannya nuansa ustadz dan kyai tidak sekental guru, karena sebutan guru di Bangka memiliki nuansa tersendiri dan muncul secara alami di tengah komunitas kepulauan ini. Adapun sebutan ustadz atau kyai merupakan pinjaman dari tradisi lokal Jawa dan kurang menyentuh kemudian terhadap masyarakat Bangka, disamping budaya patron-klien belum terbentuk. Walaupun demikian, bermunculan beberapa pondok pesantren yang dikelola oleh orang-orang tertentu yang kemudian dipanggil dan diapresiasi layaknya ustadz dan kyai di daerah lain.

${ }^{43}$ Wawancara denga Ust. Zuryaden, Rabu, tgl 14 Oktober 2015 
Shaalih wa al-Akhdzu bi al-Jadiid al-Ashlah. (Mempertahankan hal-hal lama yang baik dan mengambil sesuatu yang baru yang lebih baik). ${ }^{44}$

Sebagai lembaga pendidikan tradisional, Pondok Pesantren al-Islam Kemuja memiliki Visi kelembagaannya, yaitu: mencetak Santri Yang Berakhlak mulia ( al-Akhlaq al-Karimah ), Berwawasan Luas, Berilmu, Beramal, dan Bertaqwa menuju keridhaan Allah SWT. Sebagai muslim, santri pasti dilekatkan kepadanya akhlak sebagai bekal kepribadiannya. Santri juga tidak boleh bodoh, tapi wajib membekali dirinya dengan ilmu pengetahuan, khususnya ilmu-ilmu keislaman dasar. Sebuah pearadaban adalah ukuran dasar kualitas kemanusiaan seseorang, identik dengan kemajuan ilmu pengetahuan dan teknologi modern. Selebihnya manusia tidak boleh berdiri sendiri, melainkan mendekatkan dirinya kepada Allah, as The Ultimate Reality.

Adapun tujuan dari Pondok Pesantren al-Islam Kemuja merupakan penjabaran dari visi yang dirumuskan sebagai berikut :

1. Mencerdaskan kehidupan bangsa dalam rangka membentuk pendidikan yang berkesinambungan (long-life education)

2. Meningkatkan kualitas pendidikan dalam rangka mewujudkan sumber daya manusia yang berakhlak mulia (al-Akhlaq al-Karimah), berilmu, cakap, mandiri, komunikatif.

3. Melahirkan generasi Islam yang beriman dan bertakwa kepada Tuhan Yang Maha Esa, dan menjadi warga negara yang demokratis serta bertanggungjawab.

Ust. Zaman menambahkan tentang tujuan pendidikan Pondok Pesantren al-Islam adalah menciptakan generasi berprestasi yang berwawasan global. Tentu melekat dalam diri santri akhlak mulia. Menurutnya, belum tentu akhir kelulusan santri menjadi tolak ukur keberhasilan pondok pesantren. ${ }^{45}$ Setidaknya apa yang telah mereka dalami di lingkungan pesantren mejadi bekal untuk terjun ke tengah masyarakat. Santri-santri yang tekun dan penuh pengorbanan terkadang lebih berhasil di masyarakat dibandingkan dengan yang lebih pintar.

Singkatnya Pondok Pesantren al-Islam secara intens lakukan penguatan kelembagaan untuk tingkatkan kualitas santri walaupun kenyataannya biasa-biasa saja. Pesantren ini adalah satu-satunya di Kepulauan Bangka Belitung yang tidak pernah menolak santri yang ingin menuntut ilmu didalamnya. Apapun latarbelakang dan kondisi

\footnotetext{
${ }^{44}$ Sulaiman, Pondok Pesantren Nurul Jadid., h. 34

${ }^{45}$ Wawancara dengan Ust. Zaman Zahri, Rabu, tgl. 2 September 2015
} 
pribadi santri, tetap dibina untuk menjadi orang yang baik. Dari tidak baik kepribadiannya menjadi baik, dan seterusnya menjadi lebih baik. Jarang sekali di Pondok Pesantren alIslam pengusiran atau penonaktifan santri bila ia mencuri, kecuali sudah berkali-kali dan dalam keadaan sangat fatal/ meresahkan komunitas pesantren. Memang sudah ada buku tata terbit santri, namun sanksi yang diberikan belum terlalu tegas. Pengurus selalu berusaha agar santri di pesantren menjadi orang baik dan mampu berkiprah di tengah masyarakat. Dengan demikian santri diwajibkan mukim di asrama khususnya mereka yang berasal dari luar desa Kemuja. ${ }^{46}$ Tidak juga bagi santri yang berasal dari Kemuja, mereka hanya menempuh sekolah formal dan tidak menetap di asrama tersebut. Sepertinya sulit bagi pengurus yayasan untuk memberlakukan pola hidup kepesantrenan seperti di Jawa apalagi menanamkan aspek-aspek tentang visi dan misi, hakekat, falsafah dan idealisme Pondok Pesantren al-Islam secara intensif, mengingat masa tinggal mereka di pondok pesantren sangat sedikit. Terkadang sulit juga bagi seorang guru/ kyai membedakan siapa yang menetap dan siapa yang, "santri kalong ", sehingga proses pembinaan menjadi problematik karna bekal yang mereka miliki tidaklah sama. Bukankah metode pengklasifikasian atau pengkelompokan anak didik dalam proses pendidikan sangatlah signifikan?

Hal lain yang menjadi kendala di pesantren ini adalah terlalu banyaknya waktu libur dan tidak menentu waktu atau jam aktif sekolah. Sepertinya perencanaan kegiatan tahunan pesantren belum maksimal. Maklum yayasan Pondok Pesantren al-Islam belum memiliki kantor permanen untuk mengendalikan seluruh kegiatan pondok pesantren, sehingga keberadaannya belum sepenuhnya sebagaai sentral atau satu komando. Walaupun secara formal-melalui keputusan yayasan, program-program tertentu sudah diatur. Disepakati, namun aplikasinya agak sedikit mengalami kendala dan belum sepenuhnya didukung. Hal tersebut sangat dipengaruhi oleh luas atau tidaknya wawasan seseorang dalam berorganisasi. Pengurus yayasan Pondok Pesantren terus berupaya secara maksimal untuk melakukan terobosan pembaharuan sambil bersikap akomodatif dan tetap mempertahankan ortodoksi kepesantrenan dan budaya setempat. Pesantren mutlak diperkuat kebijakan dan ketegasannya mengacu kepada falsafah, dan idealisme pendiriannya.

${ }^{46}$ Wawancara dengan Ust. Nusroh, Senin, tgl. 24 Agustus 2015 
Secara kelembagaan, pondok pesantren semestinya memiliki fungsi, misi yang jelas sebagaimana yang diungkapkan oleh Din Syamsudin, yaitu: pertama, sebagai lembaga pendidikan keagamaan yang berfungsi menyebarluaskan dan mengembangkan ilmu-ilmu keislaman, Kedua, pesantren berfungsi sebagai lembaga pengkaderan yang telah berhasil mencetak kader umat dan kader bangsa. ${ }^{47}$

Begitu juga Pondok Pesantren al-Islam Kemuja sebagai lembaga pendidikan tertua di Kep. Bangka Belitung selalu berusaha mengelola pesantren berdasarkan visi dan misi yang dibuat. Visi dan misi tersebut harus dijadikan pijakan pengelolaan pesantren agar terarah. ${ }^{48}$ Apapun yang diputuskan setelah melalui musyawarah wajib dipatuhi oleh siapapun yang mengabdi di pesantren. Menghidupkan pesantren jauh lebih mulia daripada menggantung hidup dari pesantren.

Nilai-nilai dasar sebagai landasan, sumber acuan aktifitas di pesantren meliputi: Nilai-nilai dasar agama, nilai-nilai budaya bangsa, nilai-nilai dasar pendidikan, nilai-nilai perjuangan dan pengorbanan. ${ }^{49}$ Beberapa nilai tersebut yang mendasari juga di Pondok Pesantren al-Islam Kemuja, dimana landasan itu yang menjadi karakter dalam membina para santri di pondok pesantren supaya menjadi santri yang taat dan memiliki wawasan yang luas. Namun demikian, kehidupan di pesantren mesti identik dengan suasana yang tersimpul dalam jiwa-jiwa kepesantrenan. Jiwa-jiwa tersebut antara lain adalah bersikap ikhlas, hidup sederhana, berjiwa mandiri dan berjiwa bebas. ${ }^{50}$

Tidak begitu jelas terkait dengan tentang nilai, jiwa atau ruh kepesantrenan di Pondok Pesantren al-Islam, karena belum ada rumusan yang kuat. Namun secara implisit sudah tersirat dalam diri santri yang ditanamkan oleh para ustadz utamanya kyai-kyai senior yang masih hidup sekarang ini, dan pernah bersentuhan dengan proses pembentukan Pondok Pesantren al-Islam di awal rintisannya. Satu dua diantara mereka, masih bisa ditemui dan memberi uraian kuat tentang sejarah pesantren. Setidaknya keberadaan diri mereka memberikan sentuhan tersendiri bagi para santri saat ini. Guru pesantren idealnya adalah orang memiliki basis kepesantrenan atau setidaknya pernah belajar dari pengalaman beberapa pesantren sehingga hal tersebut memotivasinya untuk mengabdi di

\footnotetext{
${ }^{47}$ Sulaiman, Pondok Pesantren Nurul Jadid ,. h. 17-19

${ }^{48}$ Wawancara dengan Ust. Sopian, Ahad, tgl. 27 September 2015

49 Sulaiman, Pondok Pesantren Nurul Jadid, h. 24

${ }^{50}$ Sulaiman, ibid,. h. 27
} 
pesantren. Kebijakan apapun yang diterapkan akan sangat dimaklumi bagi yang memahami kehidupan di pesantren.

Memahami dan menilai pesantren tidak boleh seperti orang buta meraba gajar dan tidak seeperti kera makan manggis, seperti melihat batas, melihat secara parsial dan tidak komprehensif. Deskripsi yang persis dan benar-benar pas tentang pesantren adakah hal yang mustahil. ${ }^{51}$ Pesantren merupakan lembaga yang sangat unik, ada hal-hal yang tidak dapat diungkapkan. Belajar dan tinggal lama di sebuah pondok pesantren, belum juga memastikan bahwa seseorang memahami betul tentang kehidupan di pesantren tersebut.

Adanya landasan jiwa-jiwa kepesantrenan di Pondok Pesantren al-Islam Kemuja berhubungan erat dengan kedisplinan komunitas pondok pesantren, baik guru-gurunya maupun para santri-santri, termasuk juga pengasuh atau pimpinan pesantren. Diharapkan seorang kyai atau pimpinan menetap duapuluh empat jam di pesantren agar bisa melihat dan merasakan langsung kehidupan santri dan ustadz. Tidak ada pikiran lain dalam benak kyai selain untuk kebaikan santri dan kemajuan pondok pesantren. Pimpinan dan pengurus Pondok Pesantren al-Islam sudah diberi honororium sebagai tunjangan kehidupan mereka, bahkan diberi insentif berdasarkan masa pengabdian mereka selama ini. Mudah-mudahan hal tersebut tidak menjadi tujuan utama mereka dalam menjalankan tugas di Pondok Pesantren al-Islam.

Nampaknya pengertian, hakikat, fungsi dan visi-misi menurut Ust. Zaman Zahri, masih dapat dipertahankan, sementara ruh agak samar-samar dalam kehidupan di pesantren. ${ }^{52}$ Maka kemudian perlu ditanamkan dalam diri santri dan ustadz. Tiga hal ditawarkan Ust. Nusro untuk memperkuat kepribadian santri adalah: kesederhanaa, kebersamaan dan keseimbangan. ${ }^{53}$ Sebagai insan kamil, maka setiap santri harus berpikir logis, bersikap jujur, inovatif dan bekerja keras dalam menuntut ilmu di pesantren. ${ }^{54}$ Ketulusan jiwa seorang santri ketika belajar dan mengabdi di pesantren akan memberikan banyak hikmah bagi penguatan dirinya di masyarakat.

Satu hal yang masih menjadi kendala di Pondok Pesantren al-Islam Kemuja adalah terbatasnya sarana prasarana dan fasilitas pendidikan. Terbatasnya jumlah kelas untuk

\footnotetext{
${ }^{51}$ Sulaiman, Pondok Pesantren Nurul Jadid.,h. 2

${ }^{52}$ Wawancara dengan Ust.Zaman Zahri, Rabu, tgl. 2 September 2015

${ }^{53}$ Wawancara dengan Ust. Nusro, Senin, tgl. 24 Agustus 2015

54 Wawancara dengan Ust. Nusro, Senin, tgl. 24 Agustus 2015
} 
tempat belajar santri agak mengusik ciri khas kepesantrenan. Misalnya, di pesantren ini santri putra dan santri putri di madrasah-madrasah masih disatukan dalam satu kelas dan belum ada ketegasan tentang batas-batas hubungan komunikasi sosial antara putra dan putri kecuali penempatan asrama sebgai tempat tinggal dan musholah temnpat ibadah. Bagi santri yang sudah baligh, menginjak usia dewasa dalam hukum Islam tentu tidak dibolehkan digabung/ disatukan dalam bermu'amalah (belajar di satu kelas), kecuali dalam situasi darutrat atau benar-benar terpaksa.

\section{J. Kesimpulan}

Dengan demikian apa yang telah dilakukan selama ini setidaknya telah menggambarkan bahwa pondok pesantren, tidak diam dan bersifat stagnan, namun lembaga tersebut cukup intens lakukan terobosan-terobosan baru.

Sebagai lembaga pendidikan tradisional Islam, tidak menanggalkan falsafah dan idealisme para penggagasnya. Diharapkan dalam kondisi yang sangat terbatas lembaga tersebut terus berusaha melakukan yang terbaik. Tentu kesemuanya diperlukan kebersamaan dan saling bekerja sama secara internal, dan juga tidak ketinggalan dengan

pihak di luar pesantren selama memberikan kontribusi yang jelas untuk penguatan kelembagaan pondok pesantren.

Mudah-mudahan uraian pembahasan makalah ini setidaknya menginspirasi kita sebagai pengelola dan peminat pesantren untuk lakukan penguatan terhadap kelembagaan pondok pesantren dan berimplikasi positif terhadap proses pengabdian di pondok pesantren dan masyarakat. Tentunya kelembagaan pesantren di kepulauan ini harus diperkuat demi syiar Islam di tanah air. 
| RUSYDI SULAIMAN | Pendidikan Pondok Pesantren: Studi Atas Falsafah...

\section{DAFTAR PUSTAKA}

Abdurrahman Mas'ud, 1997, The Pesantren Architects and their socio-religious Teaching (1850-1950), (Disertasi belum dipiblikasikan), university of california Los Angeles

Abu Luis Ma'luf, 1997, al-Munjid fi al-Lughah, (Beirut: Dar al-Masyriq, cet. 22.

Abdurrahman Wahid, 2001 Menggerakkan Tradisi: Esai-Esai Pesantren, (Jogjakarta: LkiS)

Amin Haedari, 2006, Transformasi Pesantren, Pengembangan Aspek Pendidikan, Keagamaan dan Sosial, (Jakarta: Lekdis dan Media Nusantara)

Amin Haedari dan Isham el-Saha, 2006, Pesantren dan Madrasah Diniyah, (Jakarta: Diva Pustaka)

Dien Syamsudin, 2000, Etika Agama dalam Membangun Msyarakat Madani, (Jakarta: Logos Wacana Ilmu)

Dokumen yayasan pondok pesantren al-Islam Kemuja (2013)

Profil Pondok Pesantren al-Islam Kemuja (2015)

Dokumen Yayasan Pondok Pesantren al-Islam Kemuja, 2015

Imam Bawani, 1993, Tradisionalisme dalam Pendidikan Islam, (Surabaya, al-Ikhlas)

Imron Arifin, 1993, Kepemimpinan Kiyai:Kasus Pondok Pesantren Tebuireng, (Malang: Kalimashada Press) Cet. 1 
KH Hasan Abdul Wafi, Wawasan Pendidikan Pesantren, Makalah dalam Semiloka Kependidikan, di Pondok Pesantren Nurul Jadid Probolinggo Jawa Timur, tgl. 8-9 Agustus 1991

KH Imam Zarkasyi, 1970, Diktat KuliahUmum dalam Pekan Perkenalan di KMI Pondok Moderen Darussalam Gontor

KH Wahid Zaini, Paradigma Pendidikan Pesantren dalam Meningkatkan Kualitas Sumber Daya Insani, Makalah dalam Dialog Pesantren, Diselenggarakan oleh Alumni Pondok Pesantren Sunan Drajat Banjaranyar Paciran Lamongan, tgl. 20 Juni 1994

Masyhur Amin dan M.Nasikh Ridwan,1996, KH Zaini Mun'im, Pengabdian dan karya Tulisnya, (Jogyakarta: LKPSM)

Mark R.Woodward, 1999, Islam Jawa, Kesalehan Normatif versus kebatinan, terjemahan Hairus Salim AS dari Islam in Java, piety and Mysticism in The Sultanate of Jogjakarta, (Jogjakarta:LKIS)

Masdar F. Mas'udi, 1985, Mengenal Pemikiran Kuning, Dalam M. Dawam Rahardjo(Ed.), Pergulatan Dunia Pesantren: Membangun dari Bawah, (Jakarta:P3M)

M. Din Syamsuddin, 2000, Etika Agama dalam Membangun Masyarakat Madani, (Jakarta: Logos Wacana Ilmu dan Pemikiran)

M. Dawam Rahardjo (Ed.), 1985, Pergulatan Dunia Pesantren: Membangun dari Bawah, (Jakarta:P3M)

Muslim Abdurrahman, 1997, Islam Transformatif, (Jakarta: Pustaka Firdaus), Cet 3

Pradjarta Dirjosanjoto, 2001, Memelihara Umat: Kiyai Pesantren-Kiyai Langgar di Jawa, (Jogjakarta: LkiS) 
| RUSYDI SULAIMAN | Pendidikan Pondok Pesantren: Studi Atas Falsafah...

Rofiq. A, dkk, 2005, Pemberdayaan pesantren; Menuju Kemandirian dan Profesionalisme Santri dengan Metode Daurah Kebudayaan, (Jogjakarta: Pustaka Pesantren )

Rohadi Abdul Fatah, dkk, 2005, Rekonstruksi Pesantren Masa Depan (dari tradisional modern, hingga post modern, (Jakarta: PT. Listafariska Putra)

Rusydi Sulaiman, dkk, 2004, Pondok Pesantren Nurul Jadid: antara Idealisme dan Pragmatisme, (Jember:Madania Center)

Zamakhsari Dhofier, 1982, Tradisi Pesantren, Studi tentang Pandangan Hidup Kiyai, (Jakarta: LP3ES)

Zaman, 2003, Kisah Berdirinya Pondok Pesantren al-Islam (belum diterbitkan),

Zulkifli, 2002, Sufism in Java: The Role of the Pesantren in the Maintenance of Sufism in Java, (Jakarta: INIS)

Zulkifli, 2007, Kontimuitas Islam Tradisional di Bangka, (Bangka, Siddiq Press) 
Pendidikan Pondok Pesantren: Studi Atas Falsafah...| RUSYDI SULAIMAN |

EDUGAMA Vol. 5 No. 1 Juli 2019 | 29 